\title{
FERTILIZERS EFFECTS ON GROWTH PARAMETERS AND YIELD ATTRIBUTES OF FOUR COWPEA VARIETIES IN IMBO ECOLOGICAL CONDITIONS
}

\author{
KWIZERA Chantal $^{* 1}$, BANDUSHUBWENGE Denis ${ }^{2}$ \\ ${ }^{1}$ University of Burundi,Faculty of Agronomy and Bio Engineering, Department of Environment Sciences and \\ Technologies, B.P 2940 Bujumbura, Burundi \\ ${ }^{2}$ University of Burundi,Faculty of Agrinomy and Bio Engineering, Department of vegetal productions Sciences, B.P \\ 2940 Bujumbura, Burundi
}

https://doi.org/10.35410/IJAEB.2021.5615

\begin{abstract}
Nutrient depletion in soils adversely affects soil quality and reduces crop yield, especially cowpea, a plant very sensitive to insufficient fertilizers but plays an important role in the livelihood of people. A factorial experiment was conducted in randomized complete block design with three replications at imbo region. The aim of the study was to evaluate the effect of different rates of NPK fertilizers (T1 (0-0-0); T2 (12-30-30); T3 (18-48-30); T4 (23.5-60-30)) on growth parameters and yield attributes of four cowpea varieties (V1: local variety; V2: katumani; V3: Rw-CP-2; V4: Vuli). The outcomes highlighted T4 as the most effective treatment in improving the tested growth parameters of all varieties. It has played a major role by effectively increasing the plant growth, leaf area index and flowers number. Moreover, this treatment could improve grains number and weight, as well as the plants yield. Although yield attributes for variety vuli V4 were more enhanced by treatment $\mathrm{T} 3$, there was no significant difference comparatively to treatment $\mathrm{T} 4$, whence the study suggest treatment $\mathrm{T} 4(23.5-60-30)$ as the most effective treatment in improving the growth parameters and yield attributes of these four cowpea varieties, but further studies are recommended for more conclusions.
\end{abstract}

Keywords: Fertilizers, four Cowpea varieties, Growth parameters, Yield attributes, Imbo region.

\section{INTRODUCTION}

Nutrient depletion in soils adversely affects soil quality and reduces crop yield and consequently poses a potential threat to global food security and agricultural sustainability. Lower soil fertility is a potentially serious threat. It present a huge obstacles to securing needed harvest ${ }^{[1]}$. Foregoing research revealed production loss due to nutrient deficit ${ }^{[2]}$, while other research revealed lower yield due to decreased nutrient use efficiency caused by over-fertilization ${ }^{[3]}$. Furthermore, Ghaly and Alkoaik (2010) highlighted reduced plant growth, protein content and yields due to inadequate $\mathrm{N}, \mathrm{P}, \mathrm{K}$ nutrients ${ }^{[4]}$. However adequate fertilizers application affect crop yield positively. Improved crop yield has been reported due to sufficient fertilizers application ${ }^{[5]}$. It has been demonstrated that application of nitrogen fertilizer enhances early vegetative growth ${ }^{[6]}$, while Phosphorus increase yields of many crop ${ }^{[7-8]}$. Whence fertilizers management is a must in agriculture to increase crop production, especially cowpea, an important legume, very sensitive to insufficient fertilizers as reported by Chianu et 
al. (2011) and Balume (2013) who highlighted a decreased cowpea production due to declining soil fertility ${ }^{[9-10]}$. However cowpea better response due to fertilizers application in various growing areas has been affirmed by many researchers ${ }^{[11-12-13-14]}$. This crop is one of the major grain legumes in the world and is playing an important role in the livelihood of millions of people in developing countries ${ }^{[15-16]}$. It has high nutritive value and high palatability ${ }^{[17]}$. Cowpea is not only rich in nutrients, but also nutraceuticals such as dietary fibre, antioxidants and polyunsaturated fatty acids and polyphenols ${ }^{[18-19]}$. Moreover, it is a major source of protein and a

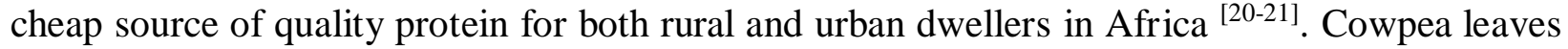
protein content is range from 27 to $43 \%$ and protein concentration of the dry grain from 21 to $33 \%{ }^{[21-22]}$. Despite all these benefit from cowpea plant, farmers are unware about fertilizers rate to apply due to newly domestication of this crop in Burundi, whence a non common fertilizers application in all regions, leading, somehow, to inadequate fertilization which results in decreased crop growth and yield. The present research study has been undertaken to analyse the effects of fertilizers on four cowpea varieties to assess the most effective rate which could effectively improve growth and yield parameters of this crop.

\section{MATERIALS AND METHODS}

\subsection{Site Description and experiment design}

The experimental site was located in imbo region at Bujumbura, in the Agricultural Sciences Institute of Burundi (ISABU) at $815 \mathrm{~m}$ of altitude. The yearly precipitation was about 1200 to $1500 \mathrm{~mm}$, with a average temperature of $23.5^{\circ}$. The soil was sandy with alot of mineral salts, a PHeau of 6.54, a soil moisture varying between 49.75 and 88.66, while the PH Kcl was 6.12. The study was carried out through experiment based on split plot model with four blocks completely randomized and three replications. These blocks were divided into 4 plots which in turnwere also divided in 4 sub plots as can be seen in figure 1. During the study, the considered factors were four different rates of fertilizers (NPK) meaning four treatments : T1 (0-0-0) without fertilizer and considered as control ; T2 (12-30-30) ; T3 (18-48-30) ; T4 (23.5-60-30), and four varieties (V1: local variety; V2: katumani ; V3: Rw-CP-2 ; V4: Vuli). Figure1 shows the details.

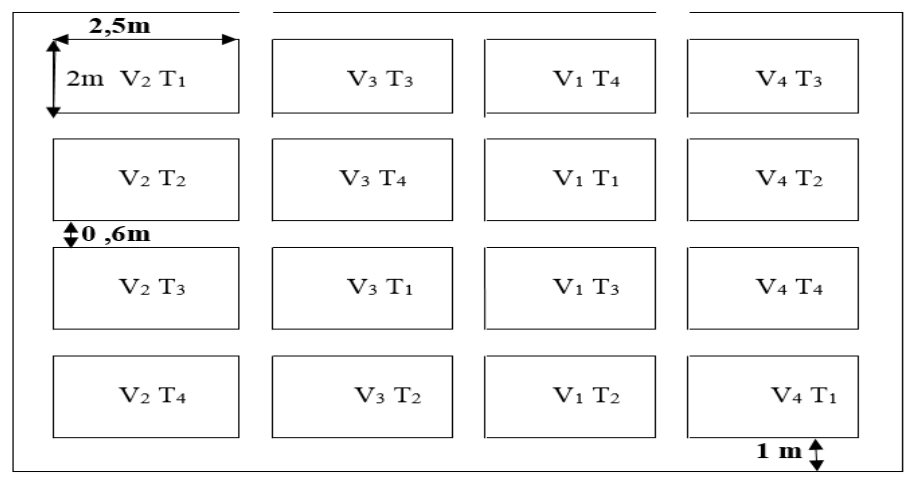


Vol. 06, No. 01; 2021

ISSN: $2456-8643$
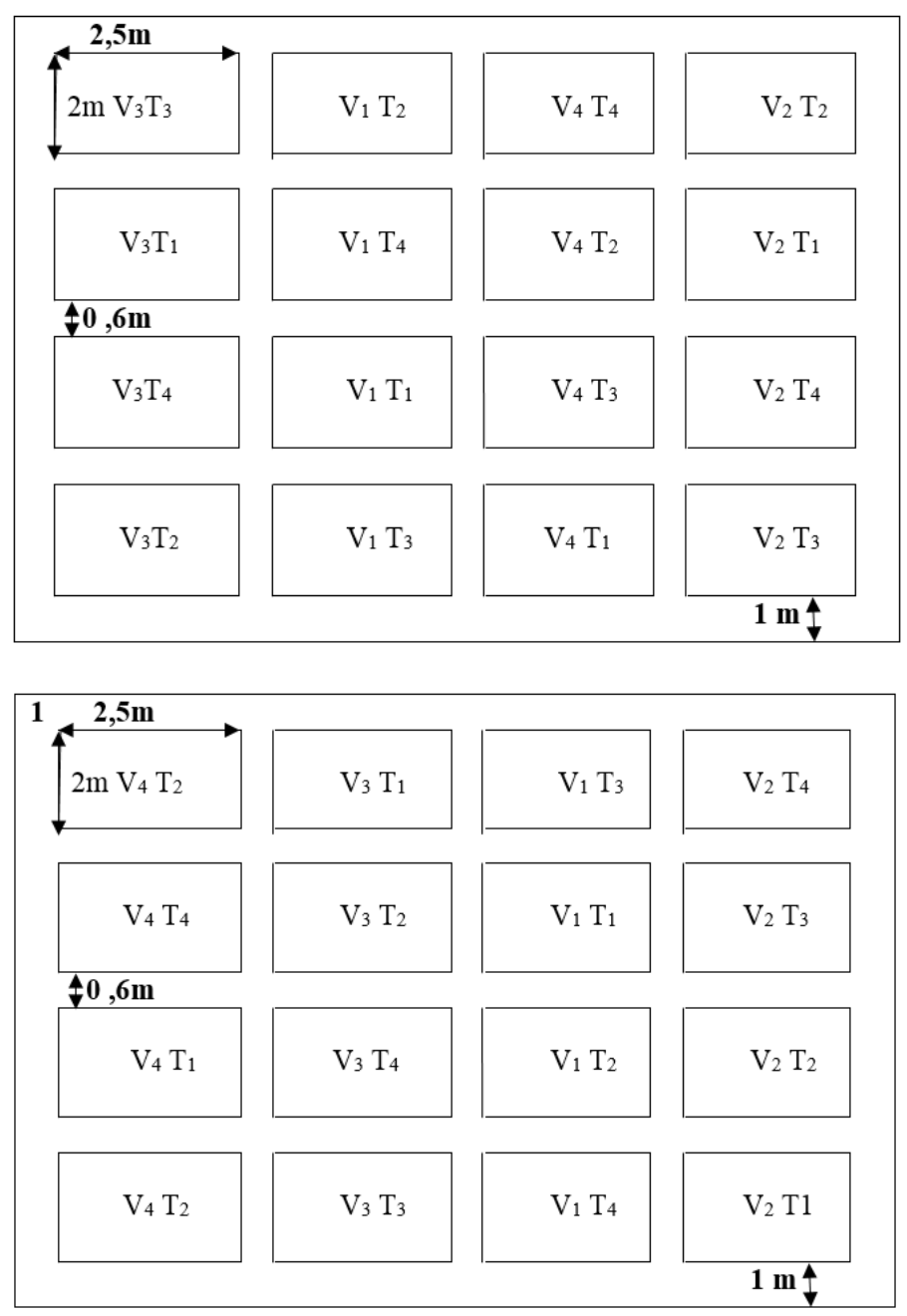

Figure 1. Experiment design

The used model for the experiment was the split-plot linear model given by the following equation :

$\mathbf{Y}_{\mathrm{ikj}}=\mu+\mathrm{R}_{\mathrm{i}}+\mathrm{V}_{\mathrm{k}}+\varepsilon_{\mathrm{ik}}+\mathrm{F}_{\mathrm{j}}+\mathrm{VF}_{\mathrm{kj}}+\varepsilon_{\mathrm{ikj}}$

Where :

$Y_{\mathrm{ikj}}$ : Represent the observation in block $\mathrm{i}$ for variety effect $\mathrm{k}$ and the rate $\mathrm{j}$ of NPK mineral fertilizer.

$\mu=$ General average;

$\mathrm{R}_{\mathrm{i}}=\mathrm{i}$ Bloc effect;

$\mathrm{V}_{\mathrm{k}}=\mathrm{k}$ varietal effect ;

$E_{\mathrm{ik}}=$ Error on the whole plot ;

$F_{j}=j$ effect of NPK mineral fertilizer rate ; 
$\mathrm{VF}_{\mathrm{kj}}=$ interaction between variety $\mathrm{k}$ and rate $\mathrm{j}$

$\varepsilon_{\mathrm{ikj}}=$ error on sub plot

$r$ : blocks number

a : level to randomize on the whole plots

$\mathrm{b}$ : level to randomize on the whole sub plot of each plot

\subsection{Data sampling}

During growth, plant heigh, leaf area index and flowers number were recorded. At maturity, data on grain number, grains weight and plant yield were assessed after oven-drying at $100^{\circ} \mathrm{C}$ to constant weight.

\subsection{Statistical analysis}

Data statistical analysis was done through Genstat Discovery Edition 4 and advanced Excel. Comparisons between treatments were conducted using Student-Newman-Keuls test at $5 \%$, while Excel was used for figures and tables.

\section{RESULTS}

\subsection{Plant height (PH) assessment}

Plant height has been tested and analysed as can be seen in Figure 2. This parameter ( $\mathrm{PH})$ changed with the variety and the used treatment.

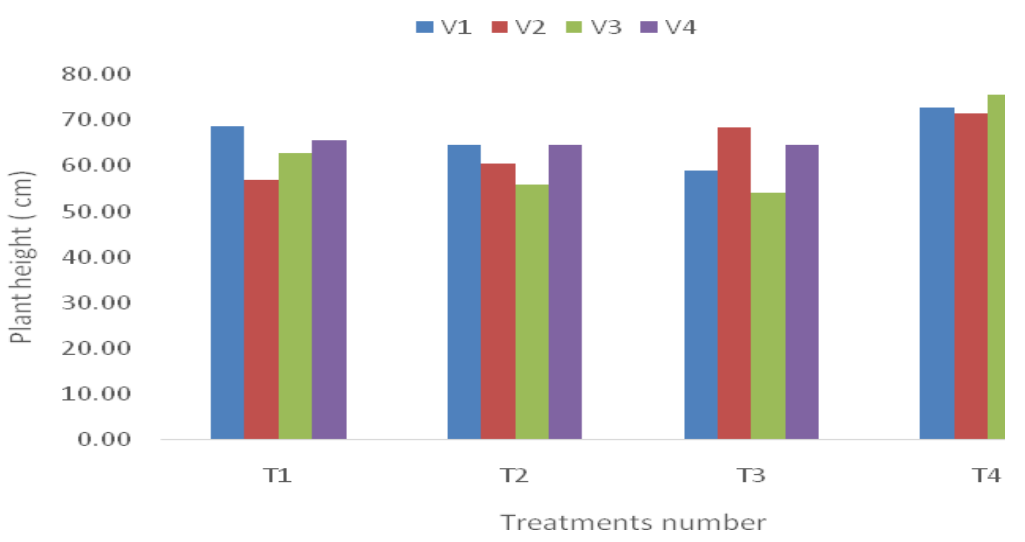

Figure 2. Effect of different treatments on plant height

The outcomes showed T4 as the most effective treatment. It has improved the plant height for all varieties with tallest plant of $72.92 \mathrm{~cm} ; 71.54 \mathrm{~cm} ; 75.54 \mathrm{~cm}$ and $67.84 \mathrm{~cm}$ for varieties V1; V2; V3 and V4 respectively. Furthermore, treatment T4 has shown significant difference with $p<0.05$ comparatively to others. The shortest plant was observed for T3 and V3 with $54.16 \mathrm{~cm}$. 


\subsection{Effects of different treatments on Leaf Area Index (LAI)}

Leaf area index evolution is summed up in Figure 2. Like for plant height, it changes following the applied rate and from a variety to an other as displayed in figure 3.

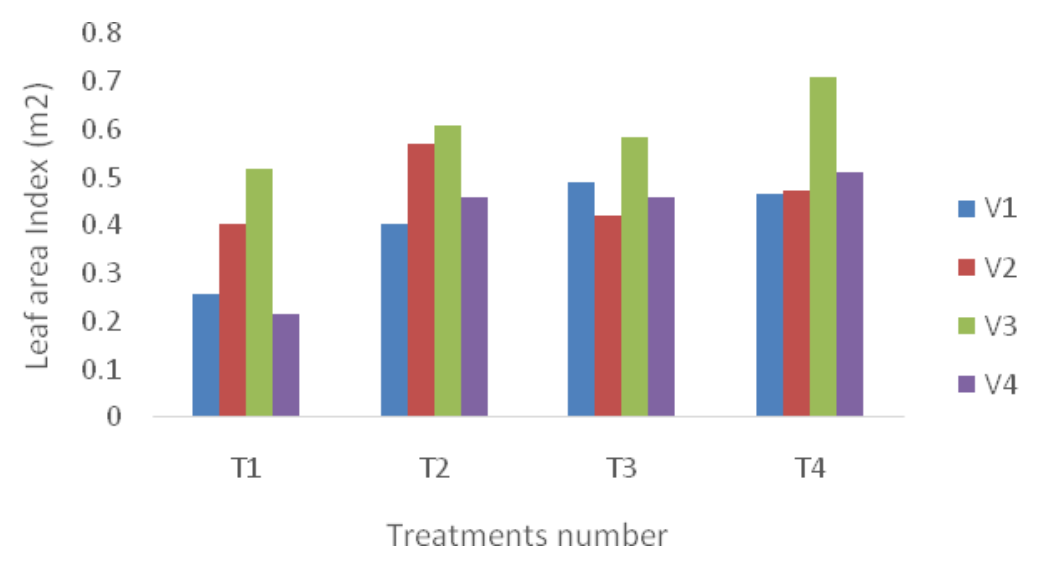

Figure 3. Leaf area index response to different fertilizers

The highest leaf area index of $0.71 \mathrm{~m}^{2}$ was recorded for treatment $\mathrm{T} 4$ on variety $\mathrm{V} 3$ and has shown significant difference comporatively to others. Moreover, this treatment has improved V4 with maximum value of $0.513 \mathrm{~m}^{2}$ as compared to others. Regarding Varieties V1 and V2, there was no significance difference between treatments. Specifically, considering V1, the highest value was observed for $\mathrm{T} 3$ with $0.49 \mathrm{~m}^{2}$, while $\mathrm{T} 4$ of $0.467 \mathrm{~m}^{2}$ was the following. The same trend was observed for variety V2, where treatment $\mathrm{T} 4$ of $0.473 \mathrm{~m}^{2}$ was the second highst after $\mathrm{T} 2$ the first highest with $0.57 \mathrm{~m}^{2}$. However for all varieties (V1, V2, V3 and V4), the minimum was recorded for treatement $\mathrm{T} 1$, the control, with $0.257 \mathrm{~m}^{2} ; 0.403 \mathrm{~m}^{2} ; 0.517 \mathrm{~m}^{2}$ and $0.217 \mathrm{~m}^{2}$ respectively.

\subsection{Flowers number $(\mathrm{FN})$ analysis}

Flowers number is an important factors for crop growth and production, figure 4 synthesizes relate results.

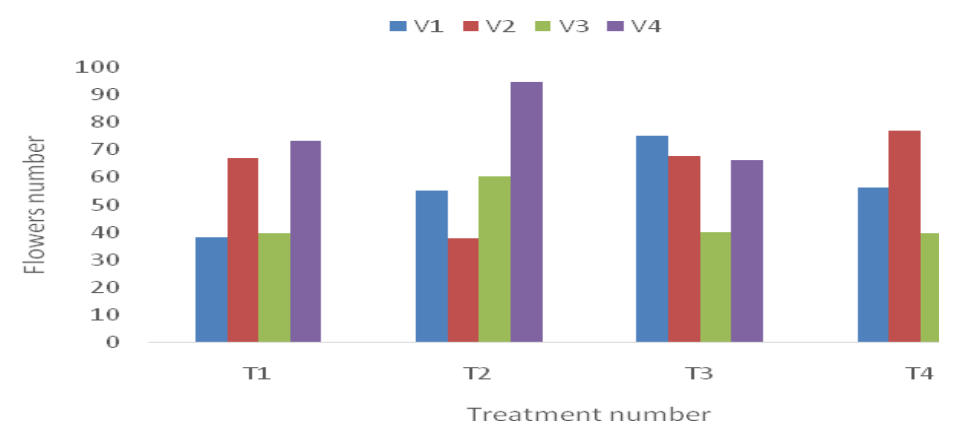

Figure 4. Flowers number evolution 
Regarding V1, the maximum value was recorded for treatment T3 of 75 flowers, followed by treatment T4 with 56 value, and minimum for the control treatment T1 of 38 flowers. Considering V2, the highest value of flowers number was observed for treatment T4 with 77 flowers, followed by treatment T3 of 68 flowers. For variety V 3, the optimum value of 61 was recorded for treatment $\mathrm{T} 2$, followed by treatment $\mathrm{T} 4$ with 40 flowers. The same trend was observed for variety V4 where the maximum flowers number of 95 was recorded for treatment T2 and second highest for T4 with 86 flowers. As can be seen in the figure, the flowers number in general was more improved by treatment $\mathrm{T} 4$ which has occupied the first or the second places for all these varieties.

\subsection{Analysis of grains number and weight per plant}

Results on grains number and weight were summed up in figures 5 and 6 . As for others analyzed parameters, grains number varies with the applied treatment and the plant variety. Although there was no significant difference, the parameter has been affected by the applied fertilizers as can be seen in figure 4. Considering V1, the highest value was observed for T4 (16 grains per plant), while the minimum was recorded for T1 (14 grains per plant). Regarding V2, the maximum was recorded for T3 (17 grains per plant) and minimum for T4 (15 grains per plant).

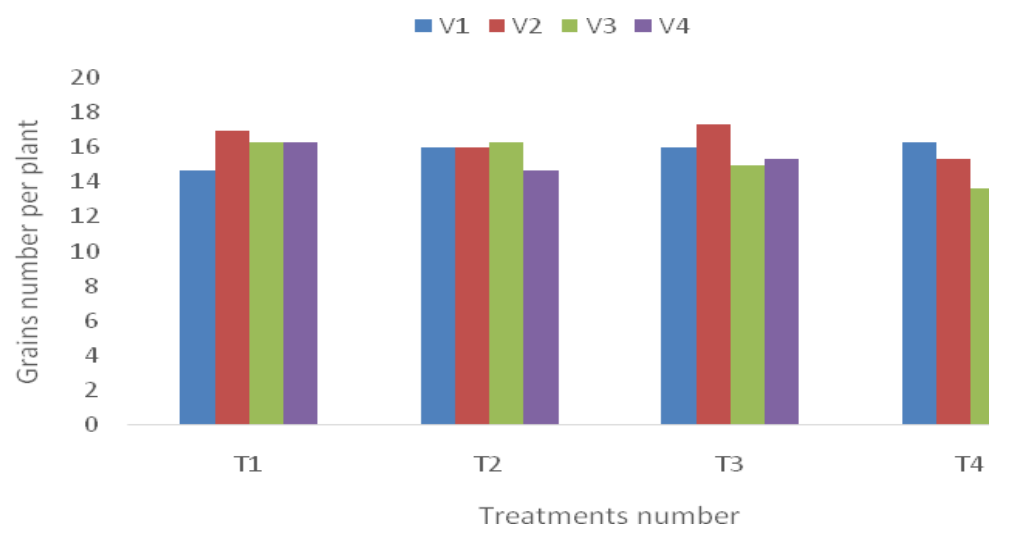

Figure 5. Grains number analysis

For V3 and V4 varieties, the maximum varies between 16 and 15 grains number, while the minimum of 13 grains was recorded for T4. Although this treatment T4 was having the minimum value for V3, it showed a second highest grains weight value for this variety. Furthermore, T4 recorded highest grains weight for $\mathrm{V} 1$ and $\mathrm{V} 2$ as can be seen in the following figure 6 . 


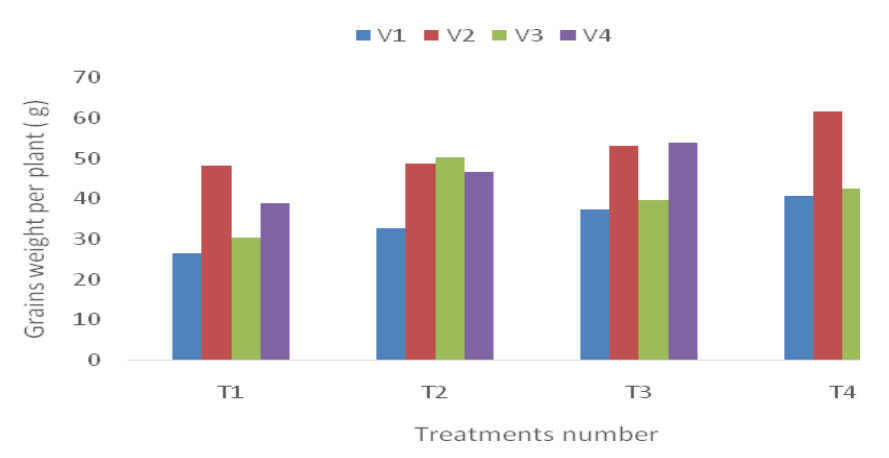

Figure 6. Evaluation of grains weight per plant (g)

Considering V1, results from this figure 6 showed maximum weight for T4 with $40.8 \mathrm{~g}$, followed by treatment T3 of $37.5 \mathrm{~g}$, and minimum for T1 by $26.7 \mathrm{~g}$. Similar pattern was observed for V2 where treatment T4 got the highest weight grains of $61.7 \mathrm{~g}$, while the minimum was recorded for treatment T1 with $48.3 \mathrm{~g}$. Considering V3, the optimum value was recorded for treatment T2 with $50.3 \mathrm{~g}$, followed by T4 treatment of $42.7 \mathrm{~g}$, and minimum for T1 with $30.4 \mathrm{~g}$. For V4, the trend changes, grains weight value was highest for treatment $\mathrm{T} 3(54 \mathrm{~g})$ but there was no significant differnce comparatively to others.

\subsection{Effects of different treatments on cowpea varieties yield (tonnes/ha)}

Plant yield assessment was shown in figure 7. As it can be seen in the figure, the maximum value was recorded for treatment $\mathrm{T} 4$ and variety $\mathrm{V} 2$.

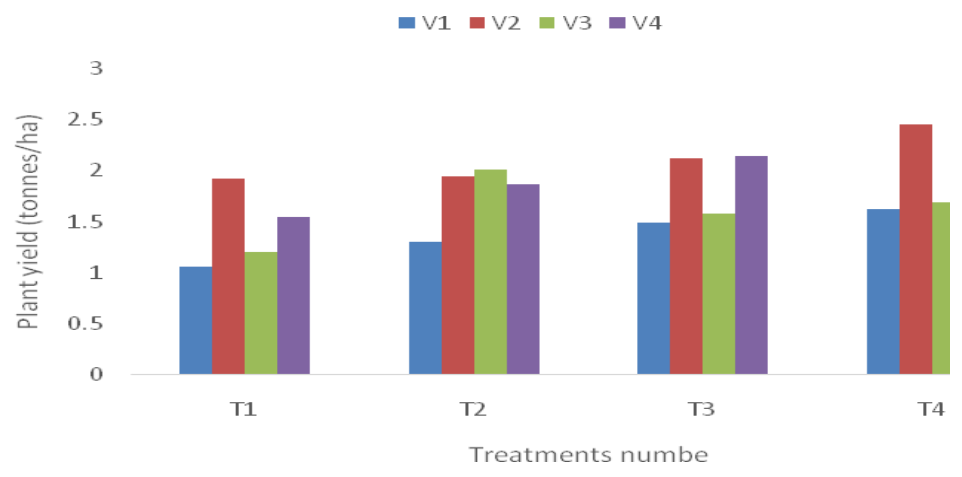

Figure 7. Plant yield (tonnes/ha) as influenced by different treatments

Trough this figure and considering V1, the outcomes showed maximum weight for T4 with 1.627 tonnes/ha. Treatment T3 of 1.497 tonnes/ha was the following, while treatment T1 of 1.063 tonnes/ha got the minimum value. As for grains number weight, treatment $\mathrm{T} 4$ was the effective treatment in increasing the plant yield for variety V2. It recorded highest yield of 2.463 tonnes/ha, followed by T3 of 2.163 tonnes/ha and minimum for the control treatment T1 of 1.929 
Vol. 06, No. 01; 2021

ISSN: $2456-8643$

tonnes/ha. Regarding V3, the trend changes, the maximum value was recorded for treatment T2 with 2.01 tonnes/ha. The second highest value was observed for T4 of 1.69 tonnes/ha, whereas the minimum of 1.21 was observed for T1, treatment used as the control. For V4, treatment T3 of 2.153 tonnes/ha showed highest value comparatively to others but no significant difference was found between treatments.

\section{DISCUSSION}

Results on plant growth parameters highlighted treatment $\mathrm{T} 4$ as the most effective treatment in improving these tested parameters. It showed highest plant height for all varieties, whence crop can assimilate sufficient light for the photosynthesis function leading to nutritious production. Moreover, this treatment $\mathrm{T} 4$ has enhanced the flowers numbers than others and has also improved leaves number, whence reduced soil evaporation leading to enhanced soil environment. This effectiveness of T4 was due to the more nutrient in this treatment which contibutes in increasing available soil nutrients whence plant can get sufficient nutrients for its growth and development. These result support those of Dart et al. (1997) and Minchin et al. (1981) who reported significant increase in growth of cowpea due to nitrogen application ${ }^{[6-23]}$. Our finding corroborates with the report of Olaleye et al. (2012) who highlighted increased cowpea growth with Phosphorus application ${ }^{[24]}$. Moreover, this treatment has effectivelly improved yield grains number and grains weight especially for V1 and V2. Also, although T4 showed lowest grains number for V3, it has, somehow, improved yield parameters for this V3 due to the second highest grains weight value that $\mathrm{T} 4$ recorded for this variety. This could probably be explained by the theory of Omueti and Oyenuga (1970) who affirmed higher nutrients synthesized for treatments with higher phosphorus application whence nutritious production for this treatment $\mathrm{T} 4{ }^{[26]}$ comparatively to others. The outcomes support the results of Abayomi et al. (2008) who reported significant increase in cowpea grain yield following the application of $\mathrm{N}$ fertilizer. Furthermore, they endorce those of Singh et al. (2011b) and Owolade et al. (2006) who reported significant effects of fertilzers on grains number and weight ${ }^{[12-27]}$. Even though T4 has effectivelly improved V4 growth parameters, it did not significantly influence the grains number, grains weigh per plant and yield of this variety V4. This could probably be explained by the fact that the highest rate of NPK used in this treatment is not the optimum rate for enhancing yield attributes of cowpea vuli (V4) variety. From foregoing research, cowpea varieties respond differently to applied fertilizer ${ }^{[28]}$.

\section{CONCLUSION}

Based on outcomes, T4 was highlighted as the most effective treatment in improving the tested growth parameters of all varieties. It has played a major role by effectively increasing the plant growth, leaf area index and flowers number. Moreover, this treatment could improve grains number and weight, as well as the plants yield. Although yield parameters were more enhanced by treatment $\mathrm{T} 3$ for variety vuli (V4), there was no significant difference comparatively to treatment $\mathrm{T} 4$, whence this treatment $\mathrm{T} 4$ could be used for V4 cultivation. Therefore, the study suggest treatment T4 $(23.5-60-30)$ as the most effective treatment in improving the growth and yield attributes of the considered four cowpea varieties, but further studies are recommended, especially for variety vuli (V4) for more clarification and conclusions. 
Vol. 06, No. 01; 2021

ISSN: $2456-8643$

\section{REFERENCES}

[1] Sanginga N, Woomer PL (2010) Integrated soil fertility management in Africa: principles, practices and developmental process (p. 13). Tropical soil biology and fertility Institute of the International Centre for tropical agriculture (TSBF-CIAT), Nairobi, pp 263

[2]Z. X. Tan, R. Lal and K. D. Wiebe ().Global Soil Nutrient Depletion and Yield Reduction. Journal of Sustainable Agriculture, Vol. 26(1) 2005. Available online at http://www.haworthpress.com/web/JSA

[3]Peng, S. et al. Strategies for overcoming low agronomic nitrogen use efficiency in irrigated rice systems in China. Field Crops Res 96, page 37-47, doi:10.1016/j.fcr.2005.05.004 (2006).

[4]Ghaly A.E. and Alkoaik F.N. 2010. Extraction of Protein from Common Plant Leaves for Use[1] as Human Food. American Journal of Applied Sciences 7 (3): 331-342, 2010

[5]Carsky, R.J. and Iwuafor, E.N.O. (1999). Contribution of soil fertility research/maintenance to improved maize production and productivity in sub-Saharan Africa. In Badu-Apraku. B., Fakorede, M.A.B., Ouedraogo, M. and Quin, F.M. (eds.). Strategy for sustainable maize production in West and Central Africa. Proceedings of a Regional Maize Workshop, 21-25 April 1997, IITA-Cotonou, Republic of Benin.

[6]Dart P, Day J, Islam RA, Dobereiner J (1997) Some effects of temperature and composition of the rooting medium in symbiotic nitrogen fixation in plant synthesis. In: Nutman RS (Ed) Tropical Grain Legume, Cambridge university press pp: 361-383.

[7] Luse RI, Kang BT, Fox RI, Nangju D, 1975. Protein quality in Grain Legumes grown in the lowland humid tropics, with special reference to West Africa, Pages 193 - 201. In Fertilizer use and Protein Production. Xith Colloquium, International Potash Institute, 1975, Ronne - Born holm, Denmark

[8] Kang BT. and Nangju D, 1983. Phosphorus Response of Cowpea (Vigna unguiculata [L]Walp). Tropical Grain Legume Bulletin 27: 11 - 16

[9] Chianu JN, Nkonya EM, Mairura FS, Chianu JN, Akinnifesi FK (2011) Biological nitrogen fixation and socioeconomic factors for legume production in sub-saharan Africa: a review. Agron Sustain Dev 31:139-154. https://doi.org/10.1051/agro/2010004

[10] Balume KMI (2013) Assessment of quality control of inoculants used on bean and soybean in eastern and central Africa. Master's thesis, University of Nairobi, Nairobi

[11]Singh AK, Tripathi PN, Room S (2007) Effect of Rhizobium inoculation, nitrogen and phosphorus levels on growth, yield and quality of kharif cowpea (Vigna unguiculata L. Walp). Crop Research Hisar 33:71-73.

[12]Singh BB, Ajeigbe HA, Tarawali SA, Fernandez-Rivera S, Abubakar M (2011b) Improving the production and utilization of cowpea as food and fodder. Field Crop Research 84: 169-177.

[13]Nkaa, F.A., Nwokeocha, O.W. and Ihuoma, O. 2014. Effect of phosphorus fertilizer

on growth and yield of cowpea (Vigna unguiculata). IOSR Journal of Pharmacy

and Biological Sciences 9: 74-82.

[14]Daramy, M.A., Sarkodie-Addo, J. and Dumbuya,G. 2016. The effects of nitrogen and phosphorus fertilizer application on crude protein, nutrient concentration and 
Vol. 06, No. 01; 2021

ISSN: $2456-8643$

nodulation of cowpea in Ghana. ARPN Journal of Agricultural and Biological Science 11: 470-480.

[15]FAO (2002) World Agriculture: towards 2015/2030. Summary report, Rome

[16]El Naim AM, Jabereldar AA (2010) Effect of Plant density and cultivar on growth and yield of cowpea (Vigna unguiculata L. Walp). Australian Journal of Basic and Applied Sciences 4: 3148-3153.

[17]Whitbread A, Lawrence J (2006) Cowpea fact sheet for Grain and Graze. Available online: White bread available on http://wa.gov.au/files/products/grain-and-graze/pn20434/pn20434.pdf. (Accessed on 19/07/2014).

[18] Phillips RD, Watters Mc, Chinnan MS, Hung YC, Beuchat LR, Sefa-Dedeh S, SakyiDawson E, Ngoddy P, Nnanyelugo D, Enwere J, Komey NS, Liu K, Mensa-Wilmot, Nnanna IA, Okeke C, Prinyawiwatkul W, Saalia FK,. Utilization of Cropea for human food. Field crop Research. 2003; 82 : 193-213

[19] Costa E. M., Nóbrega R. S. A., Martins L. V., Amaral F. H. C., Moreira F. M. S. (2011). Nodulação e produtividade de Vigna unguiculata (L.) Walp. por cepas de rizóbio em Bom Jesus, PI. Rev. Ciênc. Agron. 42 1-7. 10.1590/S1806-66902011000100001

[20]Ajeigbe H. A., Saidou A. K., Singh B. B., Hide O., Satoshi T. (2012). "Potentials for cowpea (Vigna unguiculata) for dry season grain and fodder production in the Sudan and Sahel zones of West Africa," in Innovative Research Along the Cowpea Value Chain, eds Boukar O., Coulibaly O., Fatokun C. A., Lopez K., Tamo M. [Ibadan: International Institute of Tropical Agriculture (IITA)], 189-202.

[21] Dube E., Fanadzo M. (2013). Maximizing yield benefits from dual-purpose cowpea. Food Sec. 5 769-779. 10.1007/s12571-013-0307-3

[22] Ddamulira G., Santos C. A. F., Obuo P., Alanyo M., Lwanga C. K. (2015). Grain yield and protein content of Brazilian cowpea genotypes under diverse Ugandan environments. Am. J. Plant Sci. 6 2074-2084. 10.4236/ajps.2015.613208

[23] Abudulai M., Seini S. S., Haruna M., Mohammed A. M., Asante S. K. (2016). Farmer participatory pest management evaluations and variety selection in diagnostic farmer field Fora in cowpea in Ghana.Afr. J. Agric. Res. 11 1765-1771. 10.5897/AJAR2016.10887

Olaleye O, Fagbola O, Abaidoo RC (2012) Phosphorus Response Efficiency in Cowpea Genotypes. Journal of Agricultural Science 2012. Available on- line: www.ccsenet.org/jas. Accessed on 19 May 2015.

[24]Minchin FR, Summerfield RJ, Neves MC (1981) Nitrogen nutrition of cowpea (Vigna unguiculata (L.) Walp): Effects of timing of inorganic nitrogen application. Tropical Agriculture (Trinidad) 58:1-12.

[25]Olaleye O, Fagbola O, Abaidoo RC (2012) Phosphorus Response Efficiency in Cowpea Genotypes. Journal of Agricultural Science 2012. Available on- line: www.ccsenet.org/jas. Accessed on 19 May 2015.

[26] Omueti JO. and Oyenuga VA, 1970. Effect of Phosphorus Fertilizer on the Protein and essential components of the ash of groundnut and Cowpeas. West African Biology and Applied Chemistry Journal 13(1): $299-305$ 
Vol. 06, No. 01; 2021

ISSN: $2456-8643$

[27]Owolade, O. F, Akande, M. O., Alabi, B. S. and Adediran, J. A. (2006). Phosphorus Level Affects Brown Blotch Disease, Development and Yield of Cowpea. World Journal of Agricultural Science 2(1): 105-108

[28]Abayomi Y.A., T.V. Ajibade, O.F. Sammuel and B.F. Saadudeen, 2008. Growth and Yield Responses of Cowpea (Vigna unguiculata (L.) Walp) Genotypes to Nitrogen Fertilizer (NPK) Application in the Southern Guinea Savanna Zone of Nigeria. Asian Journal of Plant Sciences, 7: $170-176$. 